\title{
AKTIVITAS ANTIKANKER EKSTRAK n-HEKSANA DAN EKSTRAK METANOL HERBA PACAR AIR (Impatiens balsamina Linn) TERHADAP SEL KANKER PAYUDARA T47D
}

\author{
THE ANTICANCER ACTIVITY IN n-HEXANE AND \\ METHANOL EXTRACTS OF Impatiens balsamina Linn HERBS \\ AGAINST BREAST CANCER CELLS T47D
}

\author{
Emma Rahmawati ${ }^{1}$, Sukardiman $^{2}$, Annisa Farida Muti $^{1}$ \\ Program Studi Farmasi Fakultas Ilmu Kesehatan, \\ Universitas Muhammadiyah Malang, ${ }^{1}$ \\ Program Studi Farmasi, Fakultas Farmasi Universitas Airlangga ${ }^{2}$
}

\begin{abstract}
ABSTRAK
Pacar Air (Impatiens balsamina Linn.) adalah tanaman yang berfungsi sebagai antikanker, antiinflamasi, antirematik, analgesik, emenagog, dan dapat melunakkan benjolan yang keras (tumor). Tujuan penelitian ini adalah untuk menguji aktivitas antikanker ekstrak n-heksana dan metanol dari herba pacar air terhadap sel kanker payudara T47D secara in vitro dengan metode MTT (microculture tetrazolium salt). Herba pacar air dikatakan memiliki aktivitasnya dilihat dari jumlah sel hidup yang telah diujikan terhadap sel kanker payudara (sel T47D) dengan metode MTT dalam rentang waktu 24 jam setelah pemberian konsentrasi larutan uji kemudian ditentukan harga $\mathrm{IC}_{50}$ dengan menggunakan probit analysis. Ekstrak n-heksan memiliki harga $\mathrm{IC}_{50} 97,493 \mu \mathrm{g} / \mathrm{ml}$ sehingga dikatakan moderate aktif terhadap sel kanker payudara T47D. Sedangkan ekstrak metanol memiliki harga $\mathrm{IC}_{50} 295,359 \mu \mathrm{g} / \mathrm{ml}$. Hasil uji KLT terbukti adanya kandungan flavonoid dan steroid.
\end{abstract}

Kata Kunci : pacar air (Impatiens balsamina Linn.), T47D, microculture tetrazolium salt (MTT) assay.

\begin{abstract}
Impatiens balsamina Linn. is a plant which can be used as anti cancer, anti inflammatory, anti rheumatic, analgesic, laxative menstruation as well as to temper tumor. The aim of this research is to examine the anti cancer activity in nhexane and methanol extracts of Impatiens balsamina Linn herbs against breast cancer cells T47D in vitro through MTT (microculture tetrazolium salt) assay. Impatiens balsamina Linn herbs are considered active referred to the amount of the living cells examined against breast cancer cells (T47D cell) through Microculture Tetrazolium Salt (MTT) assay within 24 hours after being mixed by concentration of test solution. Then, the value of $I C_{50}$ is decided by applying probit analysis. From the extracts examined, which are n-hexane and methanol
\end{abstract}


extract, $n$-hexane extract has $I C_{50}>50 \mu \mathrm{g} / \mathrm{ml}$ and $<100 \mu \mathrm{g} / \mathrm{ml}$ with the value precisely $97,493 \mu \mathrm{g} / \mathrm{ml}$ so that it can be classified as moderate active against breast cancer cells T47D. From the result of the TLC experiment, it is found that it contains flavonoid and steroid.

Keywords: Impatiens balsamina Linn, T47D, microculture tetrazolium salt (MTT) assay

\section{PENDAHULUAN}

Kanker adalah istilah umum untuk pertumbuhan sel yang tidak normal seperti sel tumbuh sangat cepat, tidak terkontrol dan tidak berirama yang dapat menyusup ke jaringan tubuh normal dan menekan jaringan tubuh normal sehingga mempengaruhi fungsi tubuh. Sel-sel kanker akan terus membelah diri dengan tidak terkendali (Diananda, 2007).

Organisasi Kesehatan Dunia menyatakan, pada tahun 2015, diperkirakan ada 9 juta orang yang meninggal karena kanker dan pada tahun 2030 diperkirakan ada 11,4 juta kematian karena kanker. Jumlah kematian akibat kanker lebih besar daripada total jumlah kematian akibat TBC, HIV dan malaria. World Health Organization (WHO) mengungkapkan terjadi peningkatan jumlah penderita kanker setiap tahunnya hingga mencapai 6,25 juta orang dan dua pertiganya berasal dari negara berkembang termasuk Indonesia (Depkes RI, 2010).

Salah satu jenis kanker yang sering terjadi saat ini adalah kanker payudara. Kanker payudara adalah kanker yang terjadi karena terganggunya sistem pertumbuhan sel di dalam jaringan payudara. Kanker payudara merupakan jenis kanker umum yang terjadi pada wanita. Hal ini berdasarkan penelitian di Amerika, yang menunjukan bahwa hampir sepertiga kanker yang didiagnosa pada wanita adalah kanker payudara (Diananda, 2007).

Beberapa usaha pengobatan kanker telah dilakukan dengan cara seperti pembedahan, radiasi, pemberian obat antikanker atau kemoterapi (Sukardja, 2000). Namun usaha-usaha ini belum memperoleh hasil yang memuaskan, bahkan efek dari kegagalan pembedahan dapat menyebabkan kanker menyebar ke bagian tubuh lain dengan kondisi yang parah (Nafrialdi dan Gunawan, 2007).

Hal ini mendorong dikembangkannya obat baru yang mempunyai efek terapi yang baik. Penelitian untuk menemukan obat antikanker antara lain dilakukan dengan menggali senyawa-senyawa alam yang berasal dari tumbuhan. Khususnya yang selama ini telah dipercaya oleh sebagian masyarakat 
sebagai obat tradisional (Mangan, 2010).

Salah satu bahan tanaman yang dapat digunakan sebagai alternatif pengobatan kanker adalah tanaman pacar air (Impatiens balsamina Linn). Bunga pacar air yang mengandung antosianin, sianidin dan malvidum berkhasiat sebagai antihipertensi dan rematik. Biji pacar air mengandung saponin, parinaric acid, kuersetin, balsaminasterol, $\alpha$ spinasterol, $\quad \beta$-ergosterol, naphtaquinon, minyak atsiri, dan derivat kamferol yang berkhasiat untuk mempermudah persalinan dan mengobati kanker saluran pencernaan atas (Dalimartha, 2003).

Tanaman pacar air sudah terbukti memiliki aktivitas sebagai antikanker. Hal ini sudah ditunjukkan pada penelitian Amelia (2011) menggunakan metode Brine Shrimp Lethality Test (BST). Berdasarkan hasil analisis yang diperoleh harga $\mathrm{LC}_{50}$ ekstrak metanol 744,4893 $\pm 85,96 \mu \mathrm{g} / \mathrm{ml}$. Dimana dinyatakan bahwa suatu tanaman mempunyai aktivitas antikanker apabila harga $\mathrm{LC}_{50}$ kurang dari $1000 \mu \mathrm{g} / \mathrm{ml}$. Dari hasil uji skrining fitokimia pada penelitian Amelia (2011) tersebut juga diketahui bahwa ekstrak metanol herba pacar air mengandung senyawa flavonoid, saponin dan steroid/triterpen yang merupakan komponen senyawa sitotoksik.

Tujuan penelitian ini adalah mengetahui aktivitas antikanker dari ekstrak n-heksan dan ekstrak metanol herba tanaman pacar air (Impatiens balsamina Linn) terhadap sel kanker payudara T47D secara in vitro dengan metode MTT. Tujuan berikutnya adalah mengetahui golongan senyawa kimia dari ekstrak herba tanaman pacar air (Impatiens balsamina Linn) yang efektif terhadap uji in vitro pada sel kanker payudara T47D dengan metode MTT.

\section{METODE PENELITIAN}

Bahan tanaman yang digunakan dalam penelitian ini adalah herba pacar air (Impatiens balsamina Linn.) yang diambil dari Materia Medika Batu, Jawa Timur kemudian diekstraksi dengan menggunakan pelarut $n$-heksana dan metanol. Bahan yang digunakan untuk uji aktivitas antikanker adalah sel kanker payudara T47D, Fetal Bovine Serum (FBS), media kultur RPMI, Dimethyl sulfoxide (DMSO), reagen MTT (3-(4,5-dimetiltiazol-2-il)-2,5difeniltetrazolium bromid), sodium duodecyl sulphate (SDS), doksorubisin. Alat-alat yang digunakan adalah rotavapor, silica gel, inkubator $\mathrm{CO}_{2}$ ELISA reader, hemasitometer.

Uji Microculture Tetrazolium Salt (MTT) Assay

Ekstrak $n$-heksana dan ekstrak metanol herba pacar air dibuat dengan konsentrasi larutan uji 
sebesar 31,25, 62,5, 125, 250 dan $500 \mu \mathrm{g} / \mathrm{ml}$. Sebagai kontrol positif digunakan doksorubisin dengan konsentrasi 6,25, 12,5, 25, 50 dan $100 \mu \mathrm{g} / \mathrm{ml}$. Masing-masing seri konsentrasi dibuat replikasi 3 kali.

Suspensi sel kanker T47D $\left(41 \times 10^{4} \mathrm{sel} / \mathrm{ml}\right)$ dimasukkan $\mathrm{ke}$ dalam plate berisi 96 sumuran dan diinkubasi selama 24 jam. Setelah 24 jam media dibuang dan dicuci dengan PBS, dimasukkan seri konsentrasi ekstrak $n$-heksana dan ekstrak metanol herba pacar air ke dalam sumuran kemudian diinkubasi selama 24 jam. Pada akhir inkubasi, larutan dalam plate dibuang dan dicuci dengan PBS 1x kemudian ditambahkan reagen MTT $100 \mu \mathrm{g}$. Sel yang telah diberi MTT diinkubasi selama 2-4 jam dalam inkubator (sampai terbentuk garam formazan). Setelah garam formazan terbentuk, ditambahkan stopper SDS 10\% dalam $\quad 0,1 \mathrm{~N} \quad \mathrm{HCl}$ kemudian diinkubasi di tempat gelap selama semalam. Setelah itu dilakukan pembacaan dengan menggunakan Elisa reader dengan panjang gelombang $595 \mathrm{~nm}$. Sel yang hidup akan bereaksi dengan MTT membentuk warna ungu.

Deteksi Senyawa Flavonoid

Hasil ekstraksi dikocok dengan 3 $\mathrm{ml} n$-heksana berulang-ulang sampai ekstrak tidak berwarna. Residu ditambah dengan $2 \mathrm{ml}$ etanol $80 \%$, kemudian disaring. Filtrate ditotol pada fase diam. Uji kromatografi lapis tipis ini menggunakan fase diam silica gel dan fase gerak kloroform-aseton-asam formiat (6:6:1) kemudian dilakukan uji KLT dengan menggunakan penampak noda uap ammonia. Adanya flavonoid ditunjukkan dengan timbulnya warna kuning.

Deteksi Senyawa Golongan Glikosida Saponin dan Triterpenoid

Hasil ekstraksi ditambah $5 \mathrm{ml}$ $\mathrm{HCl} 2 \mathrm{~N}$, dididihkan dan ditutup dengan corong berisi kapas basah selama 1 jam untuk menghidrolisis saponin. Setelah dingin, dinetralkan dengan ammonia, kemudian diekstraksi dengan $5 \mathrm{ml} n$-heksana sebanyak 2 kali, lalu diuapkan hingga tinggal $0,5 \mathrm{ml}$, ditotolkan pada plat KLT. Uji KLT ini menggunakan fase diam silica gel dan fase gerak $n$-heksana - etil asetat (4:1) kemudian dilakukan uji KLT dengan menggunakan penampak noda Anisaldehida asam sulfat. Adanya sapogenin ditunjukkan dengan adanya noda berwarna merah ungu (ungu).

\section{HASIL DAN PEMBAHASAN}

Penelitian ini menggunakan bagian herba dari tanaman pacar air (Impatiens balsamina Linn) yang diekstraksi dengan metode maserasi. Tanaman ini memiliki khasiat sebagai antiinflamasi, analgesik, antikanker, peluruh haid dan dapat melancarkan peredaran darah serta melunakkan masa atau benjolan yang keras. 
Tabel I. Hasil Pembuatan Ekstrak n-Heksana dan Ekstrak Metanol Herba Pacar Air (Impatiens balsamina Linn)

\begin{tabular}{llll}
\hline & $\begin{array}{l}\text { Berat serbuk yang } \\
\text { Ditimbang } \\
\text { (gram) }\end{array}$ & $\begin{array}{l}\text { Jumlah pelarut yang } \\
\text { digunakan untuk 3 kali } \\
\text { mama Bahan }\end{array}$ & $\begin{array}{l}\text { Berat ekstrak kental } \\
\text { (gram) }\end{array}$ \\
\hline Ekstrak n-heksana & 500 & 4,5 & 3,74 \\
Ekstrak metanol & 500 & 4,5 & 25,20 \\
\hline
\end{tabular}

Senyawa kimia yang terkandung dalam herba pacar air adalah flavonoid, saponindan steroid (Steenis, 2008 ; Dalimartha, 2003). Hasil ekstrak n-heksana dan ekstrak metanol herba pacar air (Impatiens balsamina Linn) tersaji pada Tabel I. Untuk menentukan panenan sel yang akan dimasukkan ke dalam Microwell plate 96 maka terlebih dahulu dilakukan perhitungan dengan menggunakan hemositometer. Perhitungan sel dilakukan di bawah mikroskop inverted. Hasil perhitungan sel T47D yang terdiri dari 4 kamar hitung adalah $\sum$ sel kamar $\mathrm{A}=34, \sum$ sel kamar $\mathrm{B}=58, \sum$ sel kamar $\mathrm{C}=41$ dan $\sum$ sel kamar $\mathrm{D}=30$, maka perhitungan dilakukan dengan rumus berikut :

Juml.sel terhitung $/ \mathrm{mL}=$ $\sum$ sel kamar $\mathrm{A}+\sum$ sel kamar $\mathrm{B}+\sum$ sel kamar C

$+\sum$ sel kamar D x10

Dengan menggunakan rumus tersebut sel yang digunakan untuk 100 sumuran sebanyak 2,4 ml dan media kultur yang dibutuhkan untuk 100 sumuran $=10-2,4 \mathrm{ml}=7,6 \mathrm{ml}$.
Pada penelitian ini metode yang digunakan adalah metode MTT. Metode Microculture Tetrazolium Salt (MTT) yang merupakan salah satu uji in vitro dengan menggunakan kultur sel yang digunakan untuk mendeteksi tingka ketoksikan suatu senyawa. Prinsip dari metode ini adalah adanya reaksi reduksi selular yang didasarkan pada pemecahan garam tetrazolium MTT (3-(4,5-dimetiltiazol-2-il)-2,5-difenil tetrazolium bromid) berwarna kuning menjadi kristal formasan berwarna biru keunguan (Basmal dkk, 2009). Metode perubahan warna tersebut digunakan untuk mendeteksi adanya poliferasi sel. Sel yang mengalami poliferasi akan menyerap MTT sehingga sel-sel tersebut akan berwarna ungu akibat terbentuknya kristal tetrazolium (formazan). Penambahan reagen stopper (bersifat detergenik) akan melarutkan kristal berwarna ini yang kemudian diukur absorbansinya menggunakan ELISA reader (CCRC, 2009).

Sel yang digunakan dalam penelitian ini adalah sel kanker payudara T47D. Sel T47D merupakan continous cell line yang diisolasi dari jaringan tumor duktal payudara seorang wanita berusia 54 
tahun (CCRC, 2009). Hasil absorbansi kontrol sel dan kontrol media tersaji pada Tabel II dan kondisi sel setelah perlakuan dengan metode MTT tersaji pada Gambar 1.

Tabel III menyajikan hasil uji aktivitas antikanker dari kontrol positif doksorubisin sel kanker payudara (T47D) dengan metode MTT. Hasil absorbansi sel diukur dengan Elisa reader pada panjang gelombang $595 \mathrm{~nm}$. Tabel 4 merupakan hasil uji aktivitas antikanker dari ekstrak n-heksana dan ekstrak metanol herba pacar air (Impatiens balsamina Linn) terhadap sel kanker payudara T47D dengan metode MTT. Hasil absorbansi diperoleh dari pembacaan menggunakan ELISA reader dengan panjang gelombang $595 \mathrm{~nm}$.

Gambar 2 menyatakan hubungan antara konsentrasi kontrol positif dan bahan uji terhadap persentase sel hidup kanker payudara T47D dimana semakin tinggi dosisnya, semakin sedikit sel kanker payudara T47D yang hidup. $\mathrm{IC}_{50}$ merupakan bilangan yang menunjukkan konsentrasi ekstrak yang mampu menghambat poliferasi sel sebesar $50 \%$ dan menunjukkan potensi ketoksikan suatu senyawa terhadap sel kanker. Semakin kecil nilai $\mathrm{IC}_{50}$ semakin tinggi aktivitas antikanker (Winarno, 2011).

Tabel II. Hasil absorbansi kontrol sel dan kontrol media

\begin{tabular}{lllll}
\hline \multirow{2}{*}{ Kelompok } & \multicolumn{3}{c}{ Absorbansi } & Rata-rata absorbansi \\
\cline { 2 - 4 } & $\mathrm{R} 1$ & $\mathrm{R} 2$ & $\mathrm{R} 3$ & \\
\hline Kontrol Sel & 0,730 & 0,786 & 0,730 & 0,749 \\
Kontrol Media & 0,099 & 0,100 & 0,114 & 0,104 \\
\hline
\end{tabular}

Keterangan $: R=$ replikasi ke-
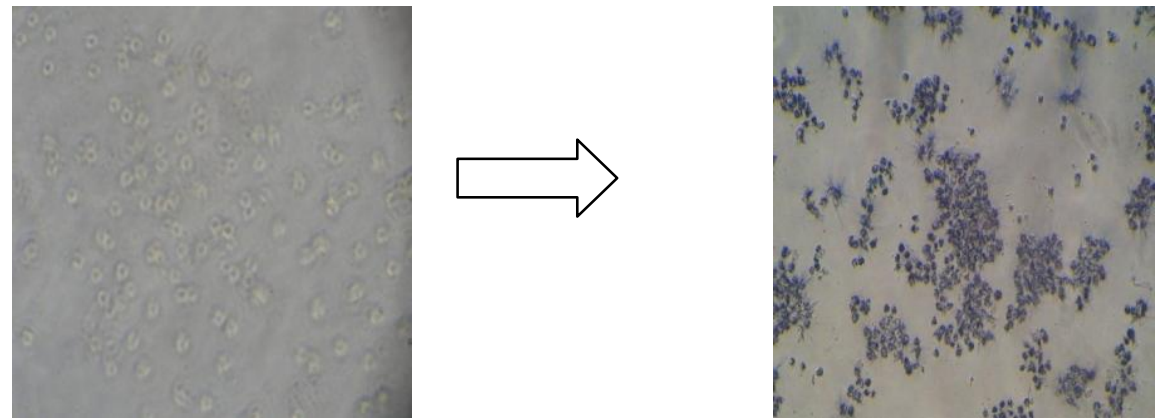

Gambar 1. Kondisi sel sebelum dan sesudah pemberian MTT dilihat di bawah mikroskop dengan perbesaran 40 kali 
Tabel III. Hasil Absorbansi kontrol positif doksorubisin

\begin{tabular}{lc}
\hline Konsentrasi kontrol positif $(\mu \mathrm{g} / \mathrm{ml})$ & Rata-rata \% sel hidup \\
\hline Doksorubisin 100 & 21,004 \\
Doksorubisin 50 & 40,507 \\
Doksorubisin 25 & 45,732 \\
Doksorubisin 12,5 & 50,181 \\
Doksorubisin 6,25 & 45,370 \\
\hline
\end{tabular}

Tabel IV. Hasil absorbansi ekstrak $n$-heksana dan ekstrak metanol herba pacar air (Impatiens balsamina Linn)

\begin{tabular}{lll}
\hline Nama bahan & Konsentrasi $(\mu \mathrm{g} / \mathrm{ml})$ & Rata-rata \% sel hidup \\
\hline \multirow{2}{*}{ Ekstrak $n$-heksana } & 500 & 1,190 \\
& 250 & 7,450 \\
& 125 & 39,731 \\
& 62,5 & 65,701 \\
& 31,25 & 99,224 \\
\hline \multirow{2}{*}{ Ekstrak Metanol } & 500 & 24,934 \\
& 250 & 50,802 \\
& 125 & 98,500 \\
& 62,5 & 94,620 \\
& 31,25 & 99,897 \\
\hline
\end{tabular}

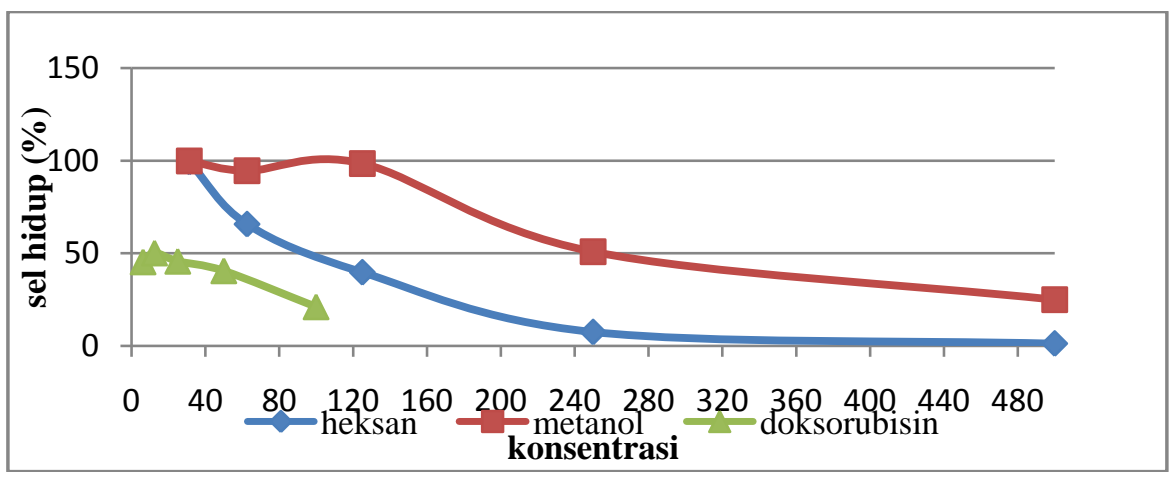

Gambar 2. Hubungan antara konsentrasi kontrol positif dan bahan uji terhadap viabilitas sel kanker payudara

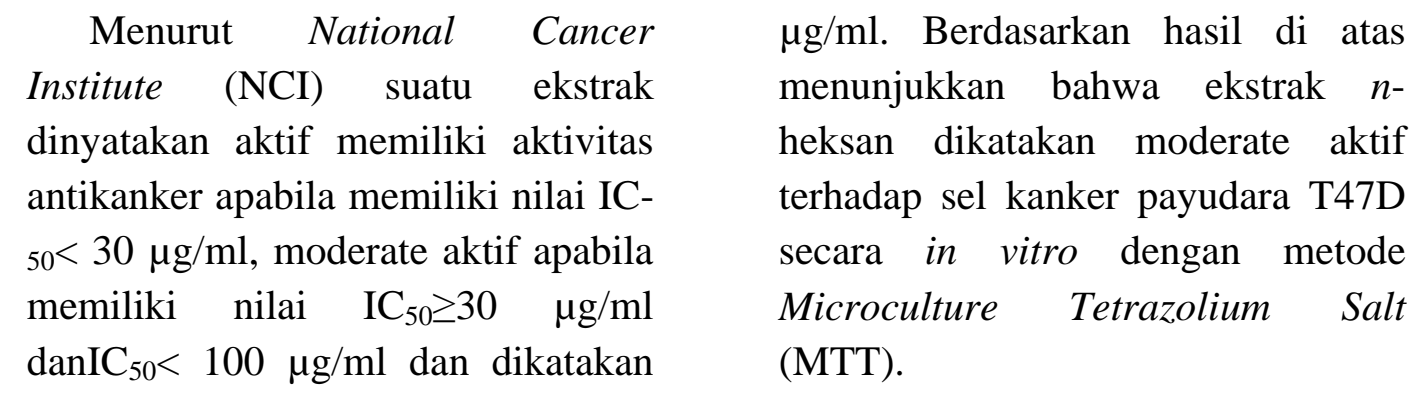
tidak aktif apabila nilailC ${ }_{50}>100$ 
Tabel IV. Hasil penentuan harga $\mathrm{IC}_{50}$ doksorubisin, ekstrak $n$-heksana dan ekstrak metanol herba pacar air (Impatiens balsamina Linn) terhadap sel kanker payudara T47D dengan probit analysis

\begin{tabular}{lc}
\hline Nama Ekstrak & Harga $\mathrm{IC}_{50}(\mu \mathrm{g} / \mathrm{ml})$ \\
\hline Doksorubisin & 8,294 \\
n- heksana & 97,493 \\
Metanol & 295,359 \\
\hline
\end{tabular}

Uji Kromatografi Lapis Tipis (KLT)

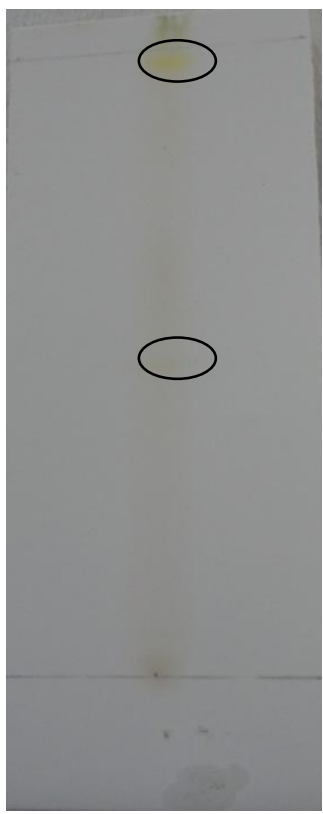

$3 . \mathrm{a}$

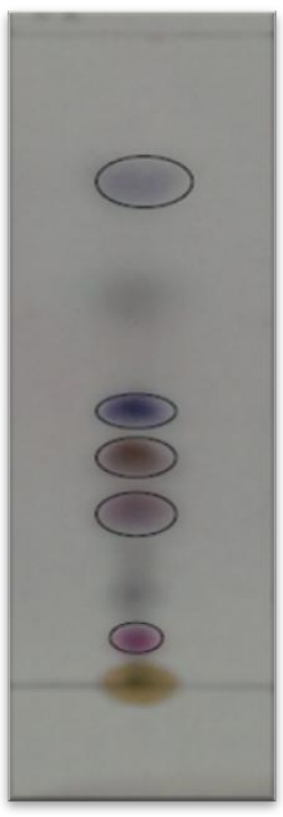

3.b

Gambar 3a. Hasil KLT ekstrak n-heksan herba pacar air dengan fase gerak kloroformaseton-asam formiat (6:6:1), penampak noda uap ammonia.

3b. Fase gerak $n$-heksana - etil asetat (4:1), penampak noda Anisaldehida asam sulfat.

Ekstrak $n$-heksana yang moderate aktif terhadap sel kanker T47D berdasarkan metode MTT selanjutnya dilakukan uji KLT untuk melihat adanya kandungan senyawa flavonoid yang berfungsi sebagai antikanker serta melihat adanya kandungan senyawa steroid.

Hasil uji KLT menunjukkan adanya kandungan senyawa flavonoid dengan timbulnya warna kuning (Gambar 3.a) serta menunjukkan adanya senyawa terpenoid dengan timbulnya warna ungu (3.b).

\section{KESIMPULAN}

Berdasarkan hasil penelitian dapat disimpulkan bahwa ekstrak nheksana herba pacar air (Impatiens balsamina Linn) memiliki harga $\mathrm{IC}_{50}$ sebesar 97,493 $\mu \mathrm{g} / \mathrm{ml}$, sedangkan ekstrak metanol herba pacar air 
memiliki harga $\mathrm{IC}_{50}$ sebesar 295,359 $\mu \mathrm{g} / \mathrm{ml}$. Hasil uji KLT menunjukkan adanya senyawa flavonoid dan terpenoid pada ekstrak n-heksana herba pacar air (Impatiens balsamina Linn).

\section{DAFTAR PUSTAKA}

Amelia, R., 2011, Uji Praskrining Aktivitas Antikanker Herba Pacar Air (Impatiens balsaminaLinn.) dengan Metode Brine Shrimp Lethality Test (BST), Skripsi, Malang: Fakultas Ilmu Kesehatan Universitas Muhammadiyah Malang.

Basmal, J., Amini, S., Sugiyono, Murniyati, 2009, Seminar Nasional Pengolahan Produk dan Bioteknologi Kelautan dan Perikanan, Jakarta.

CCRC (Cancer Chemoprevention Research Center), 2009, Preparasi sample, Yogyakarta: Fakultas Farmasi UGM.

Dalimartha, S., 2003, Atlas Tumbuhan Obat Indonesia III, Jakarta : Trubus Agriwidya.

Dalimartha, S., 2003, Ramuan Tradisional untuk Pengobatan Kanker, Cetakan VI. Jakarta : Penebar Swadaya.
Depkes, 2010, Laporan PTM Berdasarkan Rumah Sakit dan Puskesmas Kabupaten Sukoharjo. Sukoharjo: Depkes.

Diananda, R., 2007, Mengenal Seluk Beluk Kanker, Yogyakarta: Katahati.

Mangan, Y., 2010, Solusi Sehat Mencegah dan Mengatasi Kanker. Jakarta: Agromedia Pustaka.

Nafrialdi dan Gunawan, S,G., 2007, Antikanker, Farmakologi dan Terapi, Edisi ke-5. Jakarta: Departemen Farmakologi Dan Terapeutik Fakultas Kedokteran Universitas Indonesia.

National Cancer Institute, 2001, Measuring Cancer Death, Cited from http://www.cancer.gov/csr. Maret 2007

Steenis, C. G. G. J., Den Hoed, D., Bloembergen, S., dan Eyma, P. J., 2008, Flora untuk Sekolah di Indonesia, Cetakan ke-12. Jakarta : Pradnya Paramita.

Winarno, E, 2011, Uji sitoksisitas Ekstrak Kapang Aspergillus sp. terhadap Sel Kanker Payudara T47D, Skripsi, Program Sarjana Universitas Indonesia 